\title{
Design Approach for Sub-surface Flow Constructed Wetlands
}

Anish Ghimire, Ajay Kumar KC and Bijay Thapa

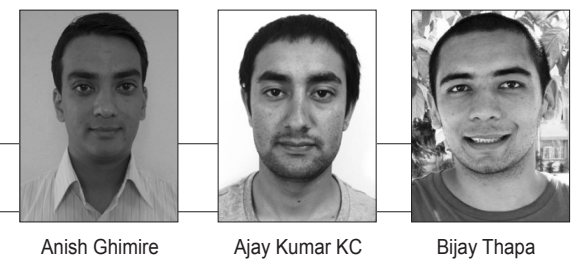

Abstract: Constructed Wetlands are an engineered wastewater treatment system that tries to mimic the natural biological, physical and chemical processes to treat wastewater. It is emerging as a cost-effective decentralized wastewater treatment solution in the communities where there is availability of inexpensive lands and lack of skilled operators. Different design approaches have been followed and design parameters based on different literatures have been chosen to design a Sub-surface Flow Constructed Wetlands. A simplified design approach well suited to climatic needs to be developed to maintain the cost effectiveness of the system. The kinetic parameters involved in the treatment should be selected properly in order to get the effective design of the system.

Key words: Constructed wetlands, wastewater treatment, subsurface flow, kinetic parameters, Nepal

\section{Introduction}

The developing countries are focusing on cost effective decentralized approach for the sanitation solutions. In recent years, Constructed Wetland (CW) systems have emerged as cost effective options to wastewater (WW) treatment. In Nepal, CWs are becoming a popular method of wastewater treatment in decentralized WW treatment plants, as these systems are well suited for small communities where land is inexpensive and skilled operators are hard to find.

Constructed wetland treatment plants in Nepal have shown good performances like asabove $85 \%$ of removal fororganic load, 58\% for total nitrogen, $75 \%$ for phosphorous (as orthophosphate-phosphorous), above $95 \%$ for total suspended solids (TSS), 62\% for ammonia, etc.(Bista 2003, Bista and Khatiwada 2004).Generally, pretreatment of wastewater is required to remove grit particles and suspended solids that might decrease the efficiency of CWs by clogging the filter media. The pollutants are removed within the wetlands by several complex physical, chemical and biological processes. But the major basic mechanism in thepollutants removalis aerobic and anaerobic microbial degradation by the variety of organisms in the CWs.

In Nepal mostlySub-surface Flow Constructed Wetland (SFCW) systems are adopted for decentralized wastewater treatment plant. Bista (2003) reported that a first full scale SFCW was introduced to treat wastewater from the Dhulikhel Hospital, Dhulikhel Municipality, Nepal in July 1997. Later, the Kathmandu University/ Dhulikheland Malpi International School/ Panauti, Nepaladopted these systems to treat domestic wastewater. Since, then these systems have become established wastewater treatment options for decentralized systems. This paper mainly deals with the review on the design considerations for SFCW systems.

In SFCW systems, a hybrid configuration is popular; i.e., a combination of both Horizontal Flow Bed (HFB) and Vertical Flow Bed (VFB)CWs. In HFB, wastewater is fed at one side of the bed and flows slowly in a more or less horizontal path through the porous media under the surface the bed and moves out of the basin through the outlet structure on the other side. By comparison, inVertical Flow (VF) thewater is fed from the top and gradually percolates down through the filter media and collected with the help of under drains systems. A graphic representation of these systems isshown in Figures 1 and 2.

Hybrid systems have the advantage of both the systems

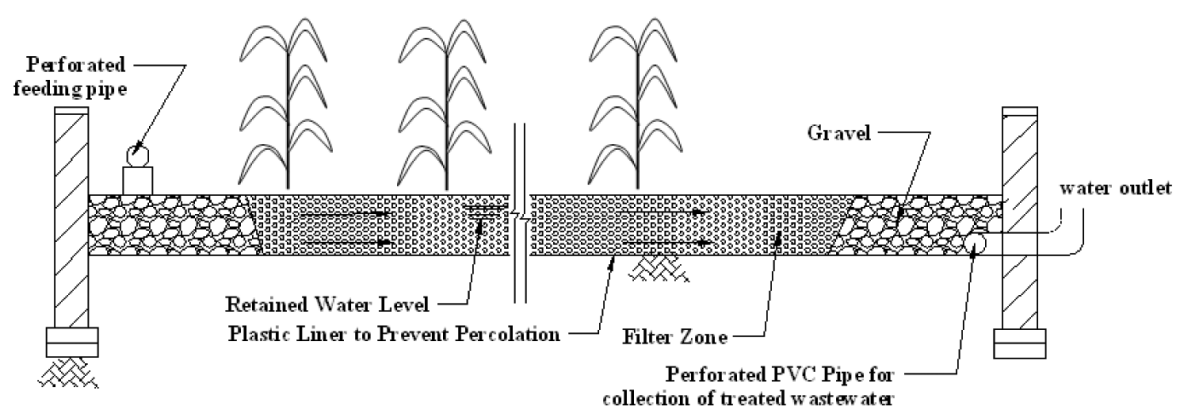

Figure 1. A Typical Cross Section of HFB . ollection of treated $w$ astew ate

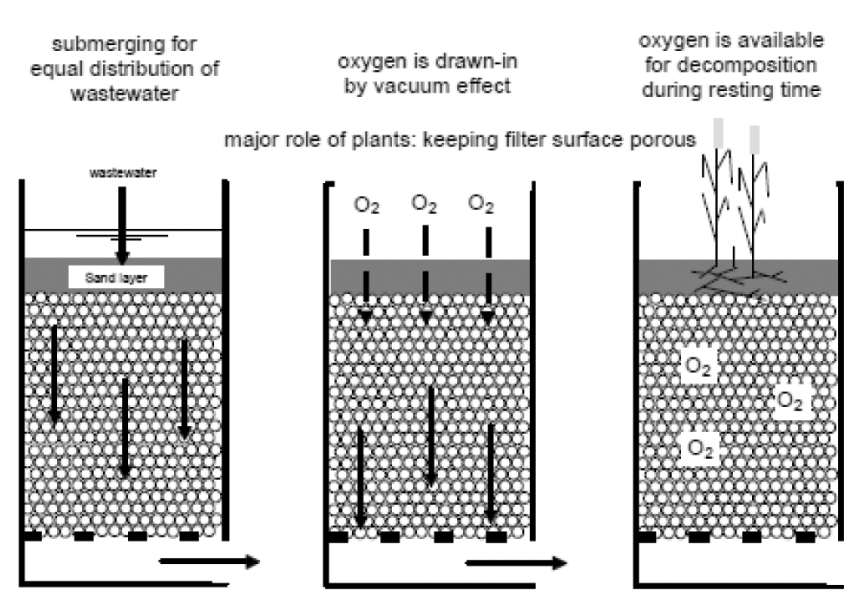

Figure 2. Principle of Vertical Flow Bed (Sasse 1998). 
in the removal of pollutants. So, there has been a growing interest in hybrid systems. Hybrid CWs could be either HFB wetland followed by VFB wetland or VFB wetland followed by HFB wetland depending on the purpose; i.e., the removal of pollutants such as organic loads, other nutrients removal (UN-HABITAT 2008). This hybrid configuration is popular due to the advantage of better nitrogen removal efficiency of VFB and good COD removal efficiency of HFB (Bista 2003;UN-HABITAT 2008).

\section{Design Principle of CW Systems}

The various models have been designed and tested for the removal of organic pollutants from the wastewater. The plug flow model seems to provide a reasonable approximation of performance in SF constructed wetlands (EPA 1993). The various design models are principally derived from the basic plug-flow equation. A basic plugflow equation is expressed in the Equation 1.1.

$$
\mathrm{C}_{\mathrm{e}}=\mathrm{C}_{\mathrm{i}} \mathrm{e}
$$$$
\text { Where, } \mathrm{K}_{\mathrm{r}} \mathrm{t}
$$

$\mathrm{C}_{\mathrm{i}}=$ Influent $\mathrm{BOD}_{5}$ concentration $(\mathrm{mg} / \mathrm{l})$,

$\mathrm{C}_{\mathrm{e}}=$ Effluent $\mathrm{BOD}_{5}$ concentration $(\mathrm{mg} / \mathrm{l})$,

$\mathrm{K}_{\mathrm{T}}=$ Temperature dependent rate constant $\left(\mathrm{d}^{-1}\right)$,

$\mathrm{t}=$ Hydraulic Retention Time (HRT), $\left(\mathrm{d}^{-1}\right)$

The $\mathrm{BOD}_{5}$ concentration of effluent wastewater is determined by wastewater effluent discharge standards into the surface water bodies and it is dependent on Environmental standards and guidelines of a country.

The temperature dependence of reaction rate constant in Equation 1.1 is derived from the Van't Hoff- Arrhenius relationship:

$$
\mathrm{K}_{\mathrm{T}}=\mathrm{K}_{2 \mathrm{O}}(\theta)^{(\mathrm{T}-20)}
$$

Where,

$\mathrm{K}_{20}=$ Rate constant at $20^{\circ} \mathrm{C}\left(\mathrm{d}^{-1}\right)$,

$\mathrm{T}=$ Operational temperature of system $\left({ }^{\circ} \mathrm{C}\right)$

The value of temperature coefficient $(\mu)$ has been found to vary 1.056 in the temperature range between 20 and $30^{\circ} \mathrm{C}$ to 1.135 in the temperature range between 4 and $20^{\circ} \mathrm{C}$ (Tchobanoglous, Burton and Stense 2003). The value of 1.06 has been used by the US Environmental Protection Agency (EPA) for the design of wetlands. Similarly, value $1.104 \mathrm{~d}^{-1}$ for $\mathrm{K}_{20}$ has also been adopted by the EPA. Therefore,

$$
\mathrm{K}_{\mathrm{T}}=\mathrm{K}_{20}(1.06)^{(\mathrm{T}-20)}
$$

The retention time also known as Hydraulic Retention Time (HRT) can be expressed as,

From equations 1.1 and 1.4,

$$
\mathrm{t}=\frac{\mathrm{LWdn}}{\mathrm{Q}_{\mathrm{d}}}=\frac{\mathrm{A}_{\mathrm{g}} \mathrm{dn}}{\mathrm{Q}_{\mathrm{d}}}
$$

Where,

$$
\begin{gathered}
t=\frac{\ln C_{i}-\ln C_{e}}{K_{T}}=\frac{A_{s} d n}{Q_{d}} \\
A_{s}=\frac{Q_{d}\left(\ln C_{i}-\ln C_{e}\right)}{K_{B O D}}
\end{gathered}
$$

$\mathrm{A}_{\mathrm{s}}=$ Surface area of bed $\left(\mathrm{m}^{2}\right)=\mathrm{L} \times \mathrm{W}$

$\mathrm{Q}_{\mathrm{d}}=$ Average daily flow rate of sewage $\left(\mathrm{m}^{3} /\right.$ day)

$\mathrm{K}_{\mathrm{BOD}}=$ Areal removal rate constant at $\mathrm{T}{ }^{\circ} \mathrm{C}, 10$

$/ \mathrm{d}=\mathrm{K}_{\mathrm{T}} \cdot \mathrm{d} \cdot \mathrm{n}$

$\mathrm{d}=$ Depth of water column (m)

$\mathrm{n}=$ Porosity of the substrate medium (percentage expressed as fraction)

An appropriate value of $\mathrm{K}_{\mathrm{BOD}}$ can be selected from the Figures 3 and 4 for HFB and VFB and thus the surface area required to treat wastewater can be obtained from Equation 1.5.

Constructed wetlands should also integrate the

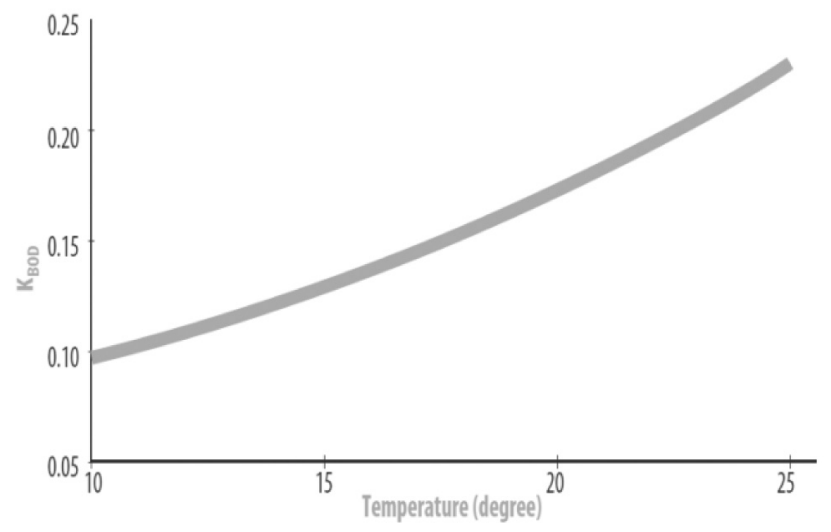

Figure 3. $\mathrm{K}_{\mathrm{BOD}}$ for HFB Plotted Against Temperature for Substrate Depth $40 \mathrm{~cm}$ and $40 \%$ Porosity (UN-HABITAT 2008).

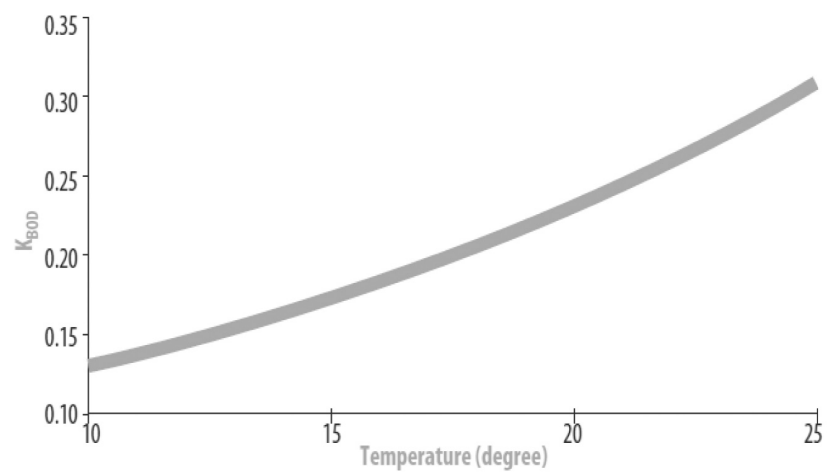

Figure 4. $\mathrm{K}_{\mathrm{BOD}}$ for VFB Plotted Against Temperature for Substrate Depth $70 \mathrm{~cm}$ and $30 \%$ Porosity (UN-HABITAT 2008).

removal of nitrogen in the design. Bavor (1988, as cited in EPA 1993) established a relation between surface area of bed and ammonia-nitrogen removal. The relation is presented in the Equation 1.6. Therefore, sizing of bed should also consider the area required for nitrogen removal.

Where,

$A_{s}=\frac{Q_{d}\left(\operatorname{lnNH} H_{i}-\ln N_{e}\right)}{K_{T} d n}$

$\mathrm{NH}_{\mathrm{e}}=$ Effluent ammonia concentration $(\mathrm{mg} / \mathrm{L})$,

$\mathrm{NH}_{\mathrm{i}}=$ Influent ammonia concentration $(\mathrm{mg} / \mathrm{L})$,

$\mathrm{K}_{\mathrm{T}}=$ Temperature dependent rate constant $\left(\mathrm{d}^{-1}\right)$,

$\mathrm{K}_{\mathrm{T}}$ can be evaluated using Equation 1.3 taking recommended values of 0.107 for $\mathrm{K}_{20}$ and 1.03 for $\theta$ 
$\mathrm{d}=$ Depth of water column (m),

$\mathrm{n}=$ Porosity of the substrate medium

(expressed as fraction)

Generally, Darcy's Law is applied when subsurface flow conditions are expected in a wetland having porous filter media. The Darcy's Law can be expressed as

$$
\mathrm{Qd}=\mathrm{A}_{\mathrm{c}} \mathrm{K}^{\mathrm{f}}(\mathrm{dH} / \mathrm{ds})
$$

Rearranging, $\quad A_{c}=\frac{Q_{d}}{K_{f}(d H / d s)}$

Where,

$\mathrm{A}_{\mathrm{c}}=$ Cross sectional area of bed $\left(\mathrm{m}^{2}\right)$

$\mathrm{Q}_{\mathrm{d}}=$ Average flow $\left(\mathrm{m}^{3} /\right.$ day)

$\mathrm{K}_{\mathrm{f}}=$ Hydraulic conductivity of fully developed bed $\left(\mathrm{m} / \mathrm{s} \mathrm{or} \mathrm{m}^{3} / \mathrm{m}^{2} / \mathrm{d}\right)$

$\mathrm{dH} / \mathrm{ds}=$ Slope of the bottom of the bed $(\mathrm{m} / \mathrm{m})$, a typical value of $1 \%$ to $2 \%$ is taken for $\mathrm{dH} / \mathrm{ds}$ (UN-HABITAT 2008)

Kadlec and Knight (1996) have given other approach for the design by including the background concentration. The background concentration occurs due to the decomposition of the wetlands sediments and litter to form $\mathrm{BOD}_{5}$.

$\ln \frac{\left(C_{e}-C^{*}\right)}{\left(C_{i}-C^{*}\right)}=-\frac{K_{B O D}}{q}=-\frac{K_{B O D} A_{s}}{Q_{d}}$

$A_{s}=\frac{Q_{d}\left(\ln \frac{C i-C^{*}}{C e-C^{*}}\right)}{K_{B O D}}$

Where,

$q=$ Hydraulic loading rate $(\mathrm{m} / \mathrm{d})$,

$\mathrm{C}^{*}=$ Background $\mathrm{BOD}_{5}$ or $\mathrm{COD}$

concentration $(\mathrm{mg} / \mathrm{l})$

\section{Existing Design Guidelines for CW Systems}

The various design guidelines can be followed during the design of wetland systems. The design parameters vary according to the place and type of system. The recommended design parameters are presented in the Table

\begin{tabular}{|c|c|c|c|c|}
\hline \multirow{2}{*}{$\begin{array}{c}\text { Design } \\
\text { Parameter }\end{array}$} & \multirow{2}{*}{ Unit } & \multicolumn{2}{|c|}{ Types of System } & \multirow{2}{*}{ References } \\
\hline & & FWS & SF & \\
\hline $\begin{array}{l}\text { Organic Loading } \\
\text { Rate, OLR (BOD } \\
\text { loading rate) }\end{array}$ & $\begin{array}{l}\mathrm{Kg} \mathrm{BOD}_{5} / \\
\text { (ha. day) }\end{array}$ & $\begin{array}{l}<110 \\
<112 \\
100-110 \\
<67 \\
<80 \\
<100\end{array}$ & $\begin{array}{l}<133 \\
<133 \\
80-120 \\
<67 \\
<75 \\
<100\end{array}$ & $\begin{array}{l}\text { Reed et al (1988) } \\
\text { EPA (1988) } \\
\text { WPCF (1990) } \\
\text { Tchobanoglous, Burton \& Stense (1991) } \\
\text { Crites (1994) } \\
\text { Reed and Brown (1995) }\end{array}$ \\
\hline $\begin{array}{l}\text { Hydraulic Loading } \\
\text { Rate, HLR }\left(\mathrm{Q} / \mathrm{A}_{s}\right)\end{array}$ & $\mathrm{cm} / \mathrm{d}$ & $\begin{array}{l}2.5-5 \\
1.4-4.7 \\
0.7-6\end{array}$ & $\begin{array}{c}6-8 \\
1.4-4.7\end{array}$ & $\begin{array}{l}\text { WPCF (1990) } \\
\text { Tchobanoglous, Burton \& Stense (1991) } \\
\text { Crites (1994) }\end{array}$ \\
\hline $\begin{array}{l}\text { Hydraulic Reten- } \\
\text { tion Time, HRT }\end{array}$ & days & $\begin{array}{l}5-10 \\
4-14 \\
5-14\end{array}$ & $\begin{array}{l}5-10 \\
4-14 \\
2-7\end{array}$ & $\begin{array}{l}\text { WPCF (1990) } \\
\text { Tchobanoglous, Burton \& Stense (1991) } \\
\text { Crites (1994) }\end{array}$ \\
\hline Water Depth & $\mathrm{m}$ & $\begin{array}{l}\text { Cattails }>0.15 \\
\text { Reed }>1.5 \\
\text { Bulrushes } \\
0.0075-0.25 \\
<0.5 \\
0.09-0.6 \\
0.1-0.5\end{array}$ & $\begin{array}{l}\text { NA } \\
\text { NA } \\
\text { NA }\end{array}$ & $\begin{array}{l}\text { WPCF (1990) } \\
\text { Tchobanoglous, Burton \& Stense (1991) } \\
\text { Crites (1994) }\end{array}$ \\
\hline
\end{tabular}

Table 1. Design Parameters for CWs (Khatiwada 1999, cited in Bista 2003). 1.

In addition to the design guidelines mentioned in Table 1, the effluent standards of a country also influences the design of the wetlands systems. From Equation 1.5, we can conclude that the size of the wetlands is directly related to the effluent $\mathrm{BOD}_{5}$ concentration and which is a function of effluent discharge standards. The effluent discharge standards of some parameters recommended by the Ministry of Environment of Nepal are presented in the Table 2. These are the tolerance or the maximum limits for wastewater to be discharged into inland surface waters from combined wastewater treatment plant.

Similarly, sizing of the CWs depends upon the degradation rate (reaction rate constant) of the pollutants in the wetlands and reaction rate constant is dependent on the temperature at which the CWs system functions. Equation 1.5 gives the relationship between the areal rate constant and the surface area of bed. The inverse relations shows that less areas is required to treat the effluent of same quality in tropical and subtropical countries than the temperate countries as organic pollutants degrades faster in high temperature.

Bista (2003) found that the value of Organic Loading Rate (OLR) in the HFB of Dhulikhel Hospital was $381 \mathrm{~kg} \mathrm{BOD} / /$ ha.d, which is three times higher than the guidelines value of $<133$ guided by the EPA (1988). However, even with the higher value of OLR the overall COD removal efficiency of the CWs that has HFB followed by VFB was $85 \%$. Oversized CWs increases the cost of the construction thus a CWs system should be designed keeping in mind the prior knowledge of the reaction rate or degradation rates that ultimately affects the size of the CWs and thus the cost. 


\section{Basic Design Considerations for CWs}

The principle components of the CW are the basic concern for its design and construction. The following considerations must be taken into account in the design of Sub-surface Flow Constructed Wetlands Systems (SFCWs).

\begin{tabular}{|l|l|}
\hline \multicolumn{1}{|c|}{$\begin{array}{c}\text { Design } \\
\text { Considerations }\end{array}$} & \multicolumn{1}{c|}{ Influence on Design } \\
\hline \multicolumn{2}{|c|}{ Site Selection } \\
\hline Temperature & $\begin{array}{l}\text { The climatic conditions of the area have an effect on the treatment system. The rate of bio-degradation in the } \\
\text { treatment system usually increases as the temperature rises and influences the size of the CWs as modeled in the } \\
\text { equations above (refer equations 1.1 and 1.5). }\end{array}$ \\
\hline Topography & $\begin{array}{l}\text { A Constructed Wetland can be constructed almost anywhere (EPA 1993). The topography has effect on the construc- } \\
\text { tion and the cost of the treatment plant. The gravitational flow system will be economical than the site requiring } \\
\text { pumping arrangements. }\end{array}$ \\
\hline $\begin{array}{l}\text { Soil Permeability } \\
\text { and Bed Sealing } \\
\text { Requirements }\end{array}$ & $\begin{array}{l}\text { Permeability of soil at site of CWs must be considered to determine the lining requirement for the constructed } \\
\text { wetlands. CWs should be lined with synthetic liners or native soil with high clay content in order to prevent } \\
\text { contamination of groundwater with the wastewater. If hydraulic conductivity of soil at the site is less than } 10^{-9} \mathrm{~m}^{3} / \\
\mathrm{m}^{2} / \mathrm{s} \text {. then there might be less chance of groundwater contamination (UN-HABITAT 2008). }\end{array}$ \\
\hline
\end{tabular}

\section{Hydraulic Design and Hydrological Conditions}

Precipitation, infiltration, evapo-transpiration (ET), hydraulic loading rate, and water depth can all affect the removal of organics, nutrients, and trace elements not only by altering the detention time, but also by either concentrating or diluting the wastewater (EPA 1988). A water budget in CW is important to calculate the average wastewater flow to the wetland. The wetland water balance for a SF constructed wetland can be expressed as:

$$
\begin{aligned}
& \text { Where, } Q_{i}-Q_{0}+P-E T=\frac{d V}{d t} \\
& Q i=\text { Influent wastewater flow }(v / t), \\
& Q 0=\text { Effluent wastewater flow }(v / t), \\
& P=\text { Precipitation }(\mathrm{v} / \mathrm{t}), \\
& E T=\text { Evapo-transpiration }(\mathrm{v} / \mathrm{t}), \\
& V=\text { volume of water, } \mathrm{t}=\text { time. }
\end{aligned}
$$

The ground water inflow and infiltration are excluded from the above equation because of the use of liner in the wetland basin. If the system operates at a constant water depth (i.e. change in volume of water, $\mathrm{dV} / \mathrm{dt}=0$ ), then, the effluent flow rate can be estimated using Equation 1.9.

Hydraulic Condic requirement for SF systems is to maintain the sub-surface condition of flow in the wetland ba hydraulic gradient can be maintained by adjusting the outlet device to maintain the water level lower at the end of the bed. EPA (1993) suggests an adjustable outlet that provides greater flexibility and control on hydraulic performance.

Aspect ratio is the Length to Width (L/W) ratio of wetland. It is important parameter in the hydraulic design since a hydraulic gradient (i.e. slope of bottom) is related to depth to length of the flow path. A low aspect ratio in the range of $0.4: 1$ to $3: 1$ is taken as appropriate for design. This range not only ensures sufficient hydraulic gradient through bed but it provides flexibility and space for the future operational adjustments (Titus 1992; EPA 1993).

\begin{tabular}{l|l} 
Aspect Ratio & $\begin{array}{l}\text { of } 0.4: 1 \text { to } 3: 1 \text { is taken as appropriate for design. This range not only ensures sufficient hydraulic gradient through bed } \\
\text { but it provides flexibility and space for the future operational adjustments (Titus 1992; EPA 1993). }\end{array}$ \\
\hline Bed slope & $\begin{array}{l}\text { SFCWs should be constructed with an appropriate bed slope to maintain an acceptable hydraulic gradient. Design } \\
\text { guidelines have recommended a bed slope of } 0.5 \text { to } 1 \% \text { for the ease of construction and proper drainage (UN-HABITAT } \\
\text { 2008; EPA 1988). }\end{array}$
\end{tabular}

\section{CW Media} \begin{tabular}{l|l} 
Selection of Media & $\begin{array}{l}\text { The selection of media is very important in the CWs. Besides providing functions like rooting material, surface area for } \\
\text { microbial growth, filtering media, it affects its hydraulic design of the CWs. Table } 3 \text { and Table } 4 \text { shows the size and the }\end{array}$
\end{tabular} characteristics of media used for the different configurations of SF wetlands.

Vegetation in CWs

Vegetation Selection

Vegetation is necessary for successful performance of CWs. UN-HABITAT (2008) listed some criteria for the selection of vegetation to be planted in the CWs. The first important criterion is the vegetation should be local dominant species. The species should have substantial biomass or stem size to achieve maximum assimilation of nutrients and deep rooted species with extended fibrous root that can provide maximum surface area for microbial population is desired in CWs. Phragmites karka (common reed) is a popular choice of vegetation for SFCWs in Nepal.

and Management

$$
\text { Inlet and Outlet Structures }
$$

Design of inlet and outlet structures plays a vital role in design of CWs as it distribute the flow into the wetland, control the flow path through the wetland, and control the water depth. To maintain uniform flow across the bed and even flow collection, multiple inlets and outlets spaced across either end of the wetland are essential (UN-HABITAT 2008).

In addition, these structures help to prevent dead zones, minimize the potential for short-circuiting, clogging in the media, supports even flow distribution and collection and also helps the operator to vary the operating water level and drain the bed.

\begin{tabular}{|l|l|} 
Inlet Structures & $\begin{array}{l}\text { Inlet structures at subsurface wetlands commonly include perforated pipes, open trenches perpendicular to the direction } \\
\text { of the flow and simple, single point weir boxes (EPA 1993). In HFB perforated or slotted manifolds running the entire } \\
\text { wetland width typically are used but in VFB there is a network of perforated pipes over the bed (as shown on Figure } \\
5 \mathrm{~d}) \text {. Designed flow rate will influence the sizes of the manifolds, orifice diameters, and spacing. Different configurations } \\
\text { of inlet structures are shown in the Figure 5. }\end{array}$ \\
Outlet Structures & $\begin{array}{l}\text { Outlet structures should help to control uniform flow throughout the CWs. For SF wetlands, perforated subsurface manifold } \\
\text { connected to an adjustable outlet provides the maximum flexibility and reliability as the outlet devices (EPA 1993). Different } \\
\text { configurations of outlet structures are shown in Figure 6. An adjustable outlet as shown in the Figure 6b is recommended } \\
\text { as it can be helpful to maintained hydraulic gradient in the bed and good operating conditions in the CWs. }\end{array}$ \\
\hline
\end{tabular}


The selection of media is different for the HFB and VFB. The recommended media types and its grain sizes are shown in Table 3.

\begin{tabular}{|c|c|c|c|}
\hline $\begin{array}{c}\text { Configuration } \\
\text { Type }\end{array}$ & Size of Media (mm) & $\begin{array}{l}\text { Type of } \\
\text { Media }\end{array}$ & References \\
\hline HFB & $\begin{array}{l}\text { Typical: } 0.2-30 \\
\text { Inlet and outlet zones: } 40-80 \\
\text { Treatment Zone: } 5-20\end{array}$ & $\begin{array}{l}\text { Medium Gravel } \\
\text { Fine Gravel }\end{array}$ & $\begin{array}{l}\text { UN-HABITAT } \\
2008, \text { EPA } \\
1993\end{array}$ \\
\hline VFB & $\begin{array}{l}\text { Typical: } 0 \text {-4 } \\
\text { Inlet zone: } 5 \text {-10 } \\
\text { Treatment zone: } 1-4 \\
\text { Outlet zone: } 20-40\end{array}$ & $\begin{array}{l}\text { Fine gravel } \\
\text { Sand } \\
\text { Medium Gravel }\end{array}$ & $\begin{array}{l}\text { UN-HABITAT, } \\
2008, \text { EPA } \\
1993\end{array}$ \\
\hline
\end{tabular}

Table 3. Sizes of Media Used in Different Configurations of Wetlands.

A typical media characteristics determined by EPA (1993) is summarized in Table 4. These properties of media are helpful in the design of the SFCWs using the mathematical equations presented in the above sections.

\begin{tabular}{|c|c|c|c|}
\hline Media Type & $\begin{array}{c}\text { Effective size } \\
\mathrm{D}_{10}(\mathrm{~mm})\end{array}$ & $\begin{array}{c}\text { Porosity } \\
\mathrm{n}(\%)\end{array}$ & $\begin{array}{c}\text { Hydraulic Conductivity } \\
\mathrm{K}_{\mathrm{f}}\left(\mathrm{m}^{3} / \mathrm{m}^{2} / \mathrm{d}\right)\end{array}$ \\
\hline Coarse sand & 2 & 32 & 1,000 \\
\hline Gravelly Sand & 8 & 35 & 5,000 \\
\hline Fine Gravel & 16 & 38 & 7,000 \\
\hline Medium Gravel & 32 & 40 & 10,000 \\
\hline
\end{tabular}

Table 4. Typical Media Characteristics for SFCWs (EPA 1993).

\section{Short Circuiting in CWs}

Velocity heterogeneity is present in nearly all wetland systems and results in some influent water remaining in the wetland for a time much shorter than the mean HRT (Lightbody, Avener and Nepf 2008). Short-circuiting flow, commonly experienced in many constructed wetlands, effects the hydraulic retention times in unit wetland cells and decreases the treatment efficiency. Design of inlet and outlet structures to maintain the even flow of wastewater can prevent the short-circuiting in the CW systems.

\section{Conclusion}

Mathematical approach is a good way to start a design of sub-surface flow constructed wetlands. In addition, a consideration of previous experience of CW's design and performance will give better results. Another approach is to follow an existing guideline. However, both approaches need careful considerations. The design guidelines presented in Table 1 are mostly based on the experimental or research studies carried in either European or North American countries. The degradation of organic matter is dependent on climatic conditions i.e. especially on temperature of a region as modeled in the equations 1.1 and 1.2. The degradation rate effects the OLR and ultimately on size and the capital cost of the CW systems. For CWs of same size, CWs in the tropical countries can take more OLR than the CWs in temperature or cold countries because of the higher rate of degradation. The mathematical models presented above can be used in the design and sizing of the sub-surface flow CWs. The existing design guidelines can also be followed with the considerations of climatic factors in the design of CWs.

Anish Ghimire is a Master's student of Environmental Engineering and Management at Asian Institute of Technology, Thailand. He also holds a B.Tech degree in Environmental Engineering from Kathmandu University, Nepal. He is General Secretary of Environment Management and Research Organization (EMRO), an NGO based in Kathmandu, Nepal. His major interest is in environmental pollution and control engineering. He also has keen interest in research areas like solid waste management, resource recovery from waste and environmental biotechnology.

Corresponding address: anishghimire@gmail.com

Ajay Kumar KC is a Master's student of Environmental Engineering at Civil Engineering Department at National Institute of Technology (NIT), Kurukshetra, India. He did his undergraduate studies at Kathmandu University, Nepal. He is Treasurer of the Kathmandu-based NGO 'Environment Management and Research Organization' (EMRO). He has also directed a short film named 'Combating Climate Change'. His research interests include water treatment, waste water and solid waste management, air pollution and climate change.

Corresponding address: kajaykc@gmail.com

Bijay Thapa is a Master's student of Environmental Engineering at Civil Engineering Department at National Institute of Technology (NIT), Kurukshetra, India. He did his undergraduate studies at Kathmandu University, Nepal. He is President of Environment Management and Research Organization (EMRO), a NGO based in Kathmandu, Nepal. His research interests include water treatment, waste water and solid waste management and air pollution.

Corresponding address: thapabijay@gmail.com

\section{References}

Bista, K.R. and N.R. Khatiwada, 2004, 'Performance study

Some photographs of the inlet and outlet structures are as follows:

Figure 5(a). Perforated Pipe Inlet (UNHABITAT 2008).

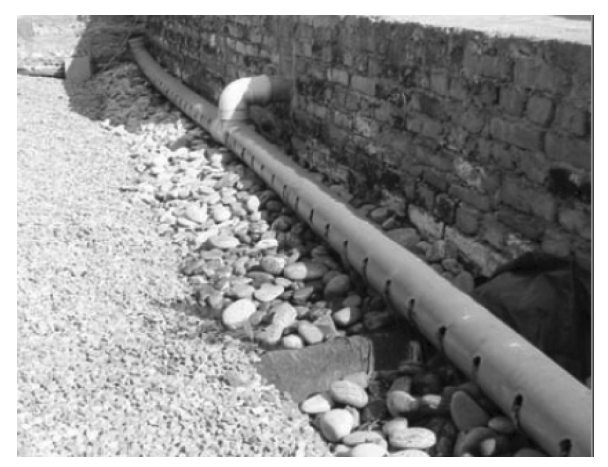



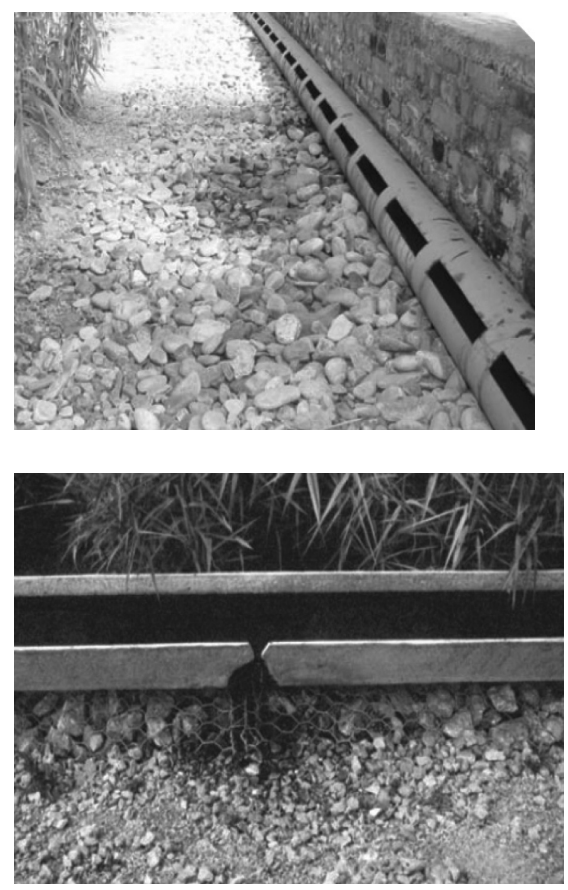

Figure 5(c) Close View of Channel inlet (Cooper et al 1996, cited in UN-HABITAT 2008) .

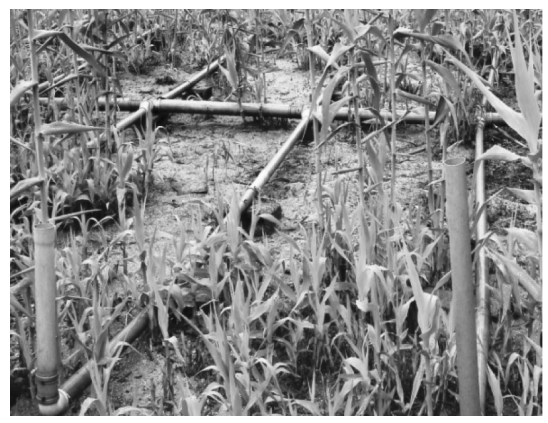

Figure 5(d). Network of Perforated Inlet Manifolds in VFB (Kathmandu University, Nepal).

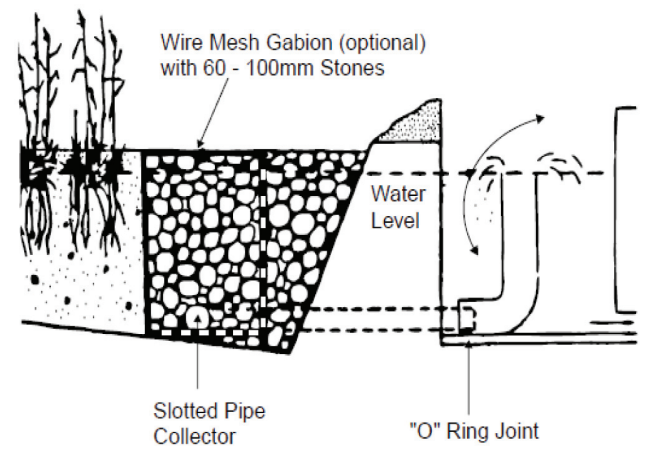

Figure 6(a). $90^{\circ}$ Elbow Arrangement (EPA 1999).

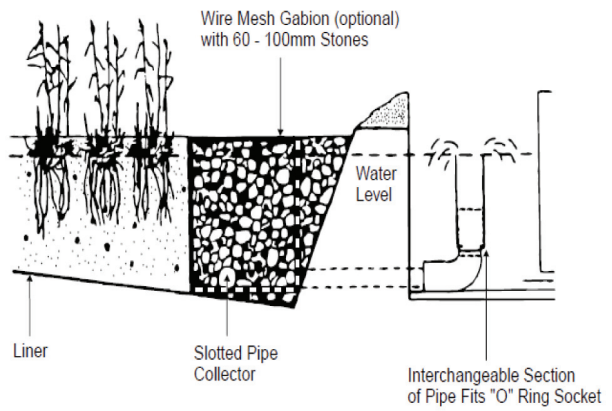

on reed bed wastewater treatment units in Nepal', in Proceedings of the International Conference on The Great Himalayas: Climate, Health, Ecology, Management and Conservation, Kathmandu, January 2004, Kathmandu: Kathmandu University, Aquatic Ecosystem Health \& Management Society and Himalayan Resources Institute.

Bista, K.R., 2003, Application of Constructed Wetland Technology for Wastewater Treatment, MSc Thesis, Kathmandu: Tribhuvan University, Institute of Engineering, Department of Civil Engineering.

Kadlec, R.H. and R.L. Knight, 1996, Treatment Wetlands, New York: Lewis Publishers.

Lightbody, A.F., M.E. Avener and H.M. Nepf, 2008, 'Observations of short-circuiting flow paths within a free-surface wetland in Augusta,Georgia, USA', Limnology and Oceanography 53(3):1040-1053. URL: www.aslo.org/lo/.

Tchobanoglous, G., F.L. Burton and H.D. Stense, 2003, Wastewater Engineering Treatment, Disposal, and Reuse, New Delhi: Tata McGraw-Hill Publishing Co.

MOE, 2010, 'Generic Standard Part III. Tolerance limits for wastewater to be discharged into Inland surface waters from combined wastewater treatment plant', in Environmental Guidelines and Collection of Related Information, Kathmandu: Ministry of Environment, Government of Nepal (original in Nepali).

Sasse, L., 1998, Decentralized Wastewater Treatment in Developing Countries, Delhi, India: Bremen Overseas Research and Development Association (BORDA). URL: $\quad$ www.ted-biogas.org/assets/download/ Sasse1998.pdf.

Titus, F.W., 1992, Sequential Nitrification/ Denitrification in Subsurface Flow Constructed Wetlands: A Literature Review, Austin, TX: Texas University, Department of Engineering.

EPA, 1988, Design Manual: Constructed Wetland and Aquatic Plant System for Municipal Wastewater Treatment, Washingtoin DC: U.S. Environmental Protection Agency.

EPA, 1993, Subsurface Flow Constructed Wetlands for Wastewater Treatment: A Technology Assessment, Washington D.C.: Municipal Technology Branch, U.S. Environmental Protection Agency.

EPA, 1999, Manual: Constructed Wetland Treatment of Municipal Wastewaters, Cincinnati, Ohio: Office of Research and Development, U.S. Environmental Protection Agency.

UN-HABITAT, 2008, Constructed Wetlands Manual, Kathmandu, Nepal: Water for Asian Cities Program, United Nations Human Settlements Program.

Some photographs of the inlet and outlet structures are as follows:

Figure 6(b). Interchangeable Section (EPA 1999). 